\title{
The use of paradigmatic research: The model of a perfect world according to Targum Qohelet
}

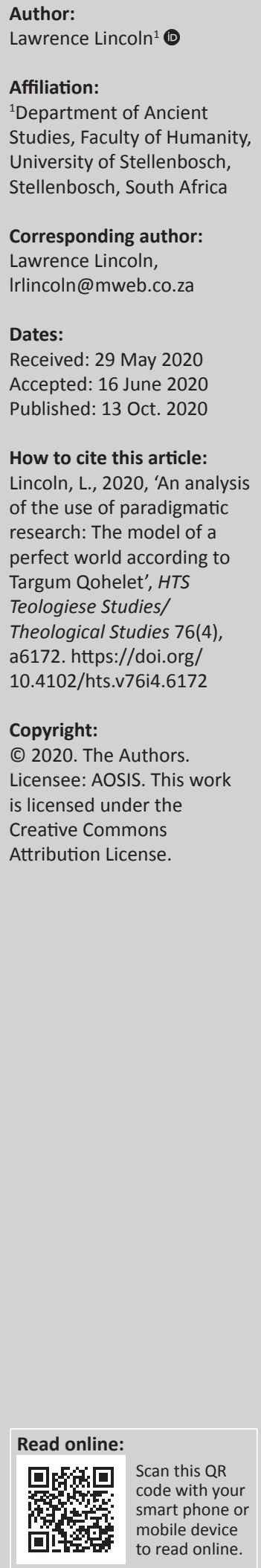

\section{Author:}

Affiliation

Department of Ancient University of Stellenbosch, South Africa

Corresponding author: Lawrence Lincoln

Dates: How to cite this article: Lincoln, L., 2020, 'An analysis research: The model of a perfect world according to Targum Qohelet', HTS Teologiese Studies/ a6172. https://doi.org/ Copyright: Licensee: AOSIS. This work is licensed under the Creative Commons Attribution License.
The purpose of this study is to identify and explain a religious paradigm in Targum Qohelet (TgQoh). Targum Qohelet is dated to a period between $500 \mathrm{CE}$ and $1101 \mathrm{CE}$. This study concludes that the most probable setting for this Targum was the beit midrash (the house of study). A paradigmatic research approach is used to identify the range of translation components to explain the translation method employed in TgQoh and the rationale behind it. This research approach reveals how the translator(s) used their interpretative ability to create a completely different thought-world when compared with the original Hebrew Text. Various subparadigms emerge as a network of connected religious beliefs to form a cogent systematic rabbinic theology of a perfect world order to replace the pessimism of the Hebrew base text. The Aramaic version reflects a complete solution to the existential problems raised by Biblical Qohelet. It seeks to provide humankind with guidelines for creating a 'perfect world' both on earth and in the afterlife. The use of a paradigmatic analysis based on the concept of a 'perfect world' provides an ideal model for analysing the translation strategy of TgQoh and understanding its method of rendering.

Contribution: The application of paradigmatic methodology bridges the gap between the relatively secular nature of the Hebrew version of Qohelet (Ecclesiastes) and the overwhelmingly and inescapable theological forms of the Aramaic targum. The paradigms in the Aramaic translation identify how the targum applied rabbinic ideology to explain the meanings that lies behind the original Hebrew text of Qohelet. The paradigms, when taken together reveal how the cynical nature of Hebrew Qohelet was changed into a rabbinical guide for righteous living, here described as 'perfect world'.

Keywords: Targum; Eschatology; Biblical interpretation; Paradigms; Translation studies.

\section{Introduction}

Aramaic Targums per se are texts produced through various translational techniques based on interpretations of their Hebrew originals. These translations range from literal or non-literal to extremely expansive and periphrastic productions. Samely defined this as, '... the Targums must be the result of a meta-linguistic attitude assumed towards Scripture's verbal matter as verbal matter' (Samely 2011:14). In other words, it does not matter how absurd and startling the Aramaic reading may be, Targum Qohelet (TgQoh) ${ }^{1}$ cannot exist as a targumic text without its verbal connection to its base text in some form or another. This point explains how TgQoh remained true to its base text, even though it is representative of one of the most non-literal examples of the Targum genre.

Targum Qohelet is a profusely theological book with hardly any verses that do not refer to Jewish theological themes (Alexander 2011:84-93; Flesher 2000:75-100; Flesher \& Chilton 2011:242; Knobel 1991:14; Levine 1978:68-72, 1988:20-30). The theology found in TgQoh is identical to rabbinic orthodox Judaism and its underlying theology. Only a few verses are translated literally from the Hebrew into Aramaic, but the rest of the narrative is transformed to reflect rabbinic theology using added and expansive renderings of the text. The aim of TgQoh was to exegetically revise Biblical Qohelet's wisdom teachings and to present its interpretation as wholly compatible with rabbinical teachings and traditions. ${ }^{2}$

1.I have used the abbreviations TgQoh and BibQoh throughout this article. To the best of my knowledge, they were first used in a series of two articles by Alexander (2011:83-101, 102-115). BibQoh refers to sections from the Hebrew Bible.

2.The dating of TgQoh is uncertain and ranges between the 7th century C.E (Knobel 1991), 8th and 9th centuries CE (Levine 1978), and Gottlieb (2014) suggested a much later date into antiquity, from 11th century or later. The consensus is a period between 500 CE as terminus a quo and 1101 as the terminus ad quem. 
The most challenging aspect of this research was to find a suitable methodology that would be able to systematically identify and explain the numerous additions and expansions, particularly on the matter of death and the afterlife (Olam $\left.H a^{\prime} b a\right)$. These are haphazardly scattered throughout TgQoh without any clear narrative logic.

This article is based on a larger study of research methodologies for the study of complex texts. The paradigmatic approach was found to be the most suitable one for analysing TgQoh as it is characterised by radical divergences from its biblical source text. Referring to the illogical and confusing narrative and its impact, Levine (1988:68) described the Aramaic version as 'depraved' and 'morally incompetent'. To overcome these challenges, this study was compelled to first identify the narrative units in TgQoh and then contextualise these within the rabbinic thought-world. Because of the immense variety and depth in rabbinic theology, this article will only focus on the paradigm of the 'perfect world', a theological concept that best describes how the targumist created an alternative text to rationalise the problems encountered in its original Hebrew version. ${ }^{3}$

\section{Paradigms}

Paradigms and paradigmatic thinking were first identified and promoted by Thomas Kuhn. He defined paradigms as 'universally recognised scientific achievements that, for a time, provided model problems and solutions for a community of researchers' (Kuhn 1962:x). In terms of theological adaptations, Hans Küng applied Kuhn's theory of paradigm change to the entire history of Christian thought and theology in which he identified what religions share in common (Küng 1993).

There has been some opposition in recent years to paradigmatic approaches but mainly in the area of the hard sciences. Paradigms when used in theological research are regarded as representative of worldviews but they are not always inclusive of all possible parameters concerning the breadth and scope of theological canons (Mittwede 2012). This study focuses on some of the paradigms specific to rabbinic eschatology and the conditions that prevailed for humankind to enter into everlasting life after death. The paradigms are relevant to the period of early and late antiquity.

Targum Qohelet is permeated with a wide range of religious additions, which explained how man and God relate to one another in a relationship that began from the time of the creation and extended into eternity (Neusner 2003:293). ${ }^{4}$ The complexity of this cosmic relationship is based on the interconnectedness of the total experiences of life and its

3.R. Judah b. Samuel Shilath said in Rav's name: The sages sought to withdraw the book of Qohelet because its words are mutually contradictory. Why did they then not withdraw it? Because it begins with words of Torah and ends with words of Torah (b. Shab.30b).

4.On theology as an organic system, see also Kadushin $(1938,1952)$. Kadushin used an alternative methodology that was based on values and ethics to delineate the alternative methodology that was based on values and ethics to delineate the
boundaries of piety and conduct within rabbinism using text-based hermeneutical boundaries of
approaches. possible continuation after death in an afterlife. Targum Qohelet connects personal conduct to a network of religious obligations, all of which will earn adherents of the merits (זכויות) to qualify for the Olam $H a^{\prime} b a$. Targum Qohelet presupposes that humankind is inherently fallible and provides for the eventuality of sin and rebellion and includes a process by which individuals are able to make right their transgressions to avoid the prospects of hell, specifically Gehenna. In TgQoh the process of forgiveness is characterised linearly as $\sin \boldsymbol{\Rightarrow}$ repentance $\boldsymbol{\Rightarrow}$ atonement $\boldsymbol{\Rightarrow}$ judgement and then a possible resurrection. The numerous interrelated religious phenomena concerning rabbinical eschatology in TgQoh, therefore, required a structured and systematic approach by which the parts of the eschatology schema can be organised, analysed and commented on. ${ }^{5}$

\section{The concept of paradigmatic categories and category formation}

The basic component of a paradigm is a 'category' as expressed through language. A category is ways of identifying, classifying and collecting all the parts of a language (lexical) terms, unique to that specific language and culture, and emerges as a recognisable theology applicable to that religion and culture (Neusner 2003:30-34, 44-46, 68-80). These language features are the 'bits of data' that are derived from collections of written documents, speech and symbols over a long time. In other words, categories create an organised whole and classify the knowledge of a specific discipline, in this case, of a religion. Categories identify and include the events, the cast of characters and the ideas of the religious events that are recorded in the Jewish canon, primarily mediated via the thought-world of the rabbinical domain. 'Categories ... (are) governed by considerations that correspond to syntax - which words combine and which cannot ... and what propositions emerge to form an intelligible account' (Neusner 2003:37, 46). When used appropriately, theological language and its vocabulary become the basis for the building blocks of a theology that is in turn modulated by the correct use of syntax and semantics. From these arise the formation of mental models or paradigms. ${ }^{6}$ In terms of Neusner's premise, categories are the 'principal organisers of inchoate data' of a theological system (Neusner 2003:36). Besides Neusner's categorisation approach, Max Kadushin also studied the complex nature of rabbinic thought but approached it through the element of cognition and how language supplied the semantics for value-concepts in haggadic thinking: He states, 'But valueconcepts ... abstract and classify, ... (and) fuse all the elements in a situation - including cognitive data - into a single entity, into a unique whole, into a particular setting' and adds, '... Rabbinic thought as a whole does possess

5.This is explained in considerable detail by Neusner (2003:36-55). The literature on the role of language in thought and action is simply too enormous to be able to record here in a footnote. Besides Neusner, see also the work of Chomsky (1993).

6.This is explained in considerable detail by Neusner (2003:36-55). The literature on the role of language in thought and action is simply too enormous to be able to record here in a footnote. Besides Neusner, see also the work of Chomsky (1993). 
coherence, an organismic, conceptual coherence which can be traced and demonstrated' (Kadushin 1952:68-70). ${ }^{7}$

Native categories identify the semantics that are central and indivisible as uniquely specific to a specific religion, such as 'Land of Israel' in the case of Judaism or the 'Cross' for Christianity (Neusner 2003:39). By illustration, 'Land of Israel' is a statement in and of itself that does not depend on other categories but can refer only to itself as a positive entity that precludes any opposite meanings. For example, when denotation 'Land of Israel' is used in a theological sense in the context of the religion and religious language, it is a native category because of its connection to rabbinic literature. It becomes theological precisely because of 'its other-than worldly or supernatural context' (Neusner 2003:41). Thus, the expression 'Land of Israel' is not only a reference to a specific nation or geographical space but also a connection to God, revelation and so on.

Paradigms enable complex texts such as religious phenomena to be able to collect a range of different subject categories and place them into a religious inventory that can be used as a sorting and clustering system from which to classify related sets of data. In philosophical terms, this would be a complete list of everything that 'there is', from 'the highest genera of activities' to the lower orders. ${ }^{8}$ Neusner (2003:48) called this sorting and classifying process a means to identify 'the structure of thought'. In the context of theology, for instance, a 'god' would be at the apex of the system, and from this point, many other categories derive; from this point, Myers (quoting Torrance), for instance, understood the ranking or sorting of religious words and grammar as contributing to stratification of religious thought in a metatheological sense (Myers 2008:1-15). The use of paradigmatic analysis is invaluable for defining and collecting any number of categories for a study that involves an immense collection of disparate data as a means to reveal how the data sets are organised and connected. The amount of 'sets of data' or categories is extensive in terms of TgQoh. These include elements such as creation, Torah study, righteousness, sin, repentance, punishment, Gehenna, Olam $H a^{\prime} b a$ and other topical elements, all of which are additions to the source text. It would be an onerous task to make any sense of how all these, and others, are interrelated and strategically utilised to present an alternative new raison d'etre for the book. An interpretative paradigmatic approach provides an ideal mechanism to analyse literary data in conjunction with exegetical practices. This position on paradigmatic analyses is applicable to the other expansive and non-literal targumim, such as the targums on Esther, Job, Song of Songs and others.

7. Kadushin explained the value and its conceptual background in terms of that which gave rabbinic thought its intrinsic character and what caused it to be unique to rabbinic theology (Kadushin 1952:3). Similarly, Neusn of Israel' that denoted a term laden with specific value to Jewish theology, but could only be understood in relation to other concepts, such as Moses, God, prophecy and other related terms that animated the specific rabbinic contexts and meanings (Neusner 2003:4-16).

8.https://plato.stanford.edu/entries/categories

\section{Religious language}

A 'specialised' language is a sine qua non for a theology (Neusner 2003:26-30). For Judaism, theological language describes every type of religious and secular experience as they are expressed through the words of the holy books, but in subservience to the primacy of Torah. For Neusner (2003:29), the language categories are recognisably uniform across various genres and texts because of their 'linguistic formalization and expression'. Accordingly, the words selected and the modes of their transmission form the narrative of how humankind meets God. The complete dominance of the Torah in all aspects of life, specifically the injunction to study the Torah throughout a person's entire life, ${ }^{9}$ is a central theme in all Targums (Levine 1988:135-139). ${ }^{10}$ The targumists, well-versed in rabbinic language, adapted the words of the Torah both metaphorically ${ }^{11}$ and practically to any of life's experiences and situations (Levine 1988:135-139) as shown here in a comparative reading between Biblical Qohelet (BibQoh) 1:3 and TgQoh 1:3:

What real value is there for a man in all the gains he makes beneath the sun. (BibQoh 1:3)

What value is there to a man, after his death, from all his labour which he laboured under the sun in this world, other than he studies the word of God, to receive a good reward in the world to come from before the Lord of the world. (TgQoh 1:3) ${ }^{12}$

The translation of TgQoh became a hermeneutical tool by including strategically targeted language in which theological categories were inserted between the Hebrew original. The language of TgQoh reflected a common rabbinic worldview/ paradigm that was easily recognisable in other Jewish texts (Alexander 2011:92). The words and phrases expressed as the 'governing language' and connected with the imagery of past Israelite history served to indicate the inherent Israelite/ Jewishness nature of the text and the governing so recognisable to its readers. ${ }^{13}$ Targum Qohelet appears confident in its translation and the authors were well steeped in the language of the sages and the theology and literary traditions of rabbinic Judaism.

\section{A perfect world ${ }^{14}$}

BibQoh introduced its readers to the author's particular worldview, in which a great deal of negative assertions is made concerning the fate of people in this world. For Qohelet,

9 G'God studies Torah a quarter of each day' (PT D $32 \cdot 4)$. Torah observance and study are the key to the Gan Eden and the afterlife (PT Gn 3:24).

10.Torah and Torah-related themes are mentioned in all the verses of TgQoh and appear 29 times in total in the book.

11.Metaphors alluding to Torah included references to 'knowledge', 'path', 'light', 'source', 'truth', 'yoke', 'strength', 'fragrance', 'work', 'rule' and even 'thirstquencher' (Levine 1988:136)

12. The English translation of TgQoh is from Levine (1978) and the Hebrew is from JPS (1985 edition), unless otherwise indicated.

13.Refer to Chomsky (1993) on the nature of the 'governing language' in the way it creates metaphors to make sense of the world. He called it 'generative language'. I he sis theory, some have used his theory, somewhat liberally, to try to explain how language is concept, but in Neusner's case, it was aligned to religious cognition (2003:26-35).

14.The terms 'perfect world, "world order" and an imperfect world' are all derived from Neusner (2003). 
God and his doings are incomprehensible to humankind. God makes "things happen" but this excludes the existence of anything that indicates a close relationship with people. As such there are no references in BibQoh of any pro-active means of communication that connects people to God and God to people employing rituals, liturgical practices and a common religious language. Qohelet is trapped by the concept of hebel, as it is continuously agitated for fatalistic outcomes for all humankind and their ability to find inner peace and self-actualisation. Schoors asks whether the generic god referred to is actually the God known as YHWH? (Schoors 2013:22). Hebrew Qohelet never used the term Adonai, but the generic appellation Elohim (seven times) and Ha-Elohim (29 times). In contrast, TgQoh was based on a theology that encouraged continuous dialogue in a symbiotic relationship with God. The connection between the deity and the people emerged over many centuries from the oral and written records of Israelite/Jewish history and its huge corpus of interpretations that slowly evolved into an allencompassing organic whole (Kadushin 1938, 1952).

Qohelet portrays the meaning of life as a futile form of existence as stated in the pericope, 'What real value is there for a man in all the gains he makes beneath the sun?' (BibQoh 1:3). Qohelet uses the term יתרוך that translates as 'advantage', 'value' or 'profit'. ${ }^{15}$ For Qohelet, a person's earthly toils, עמלו is pointless (BibQoh 2)

For what does the man get for all the toiling and worrying he does under the sun? All, his thoughts are grief and heartache, and even at night his mind has no respite. That too is futile (hebel). (vv. 22-23)

For the rabbis, the Torah contained all that man needed to know to comprehend life and to draw closer to God (Schechter 1961:127-137). Rabbinical thought equates wisdom to the Law, that is, Torah, and when TgQoh speaks of wisdom, it is always in relation to Torah wisdom. This notion of wisdom as integral and deriving from the Law/Torah has ancient roots and can exegetically be traced back to Deuteronomy 4:6, 30:11-18. Interpretation became wisdom and was present as an active participant with God at the time of the world's creation (Pr 8:22-30) (Moore 1970:263-267; Schechter 1961:116). ${ }^{17}$

In BibQoh, it was apparent in Qohelet's world that human existence was overwhelmingly random, lacked purpose and harmony, and was without any evidence of any reliable political and social frameworks. The challenge for TgQoh was to implement a translation strategy as an alternative

15.This noun, according to (Fox 1999:112) and Seow (1997:112-117), is used by Qohelet either in a commercial or philosophical sense. In the Ancient Near East (ANE), it ranges in meaning from 'abundant', 'remains over' and more, but the commentaries on these lexemes are too extensive to deal with in this article.

16.15 as a semantic unit is commonly found in wisdom literature and essentially refers to 'labour', and specifically the suffering caused by some forms of labour.

17. The literature on TgQoh is quite sparse, and no complete commentary is yet available, if one excludes the translations into English by Levine (1978) and Knobe (1991), with additional translations into Spanish by Merino (1987); and French by Manns (1992) and Taradach and Ferrer (1998). However, all current studies on the Aramaic translation are unanimous that the targum had been totally influenced by rabbinical theology. The most detailed and current study is that of Philip Alexander (2011). The commentary by Schoors (2013) on BibQoh includes the Aramaic verses with a very brief explanation for each one. The study by Flesher (2000) on the Rabbinic Rewriting of Qohelet is an important contribution. framework based entirely on religious precedent and which would have created a space in which both community and individual would be able to find certainty and direction in life in comparison with the chaos and randomness offered in BibQoh.

The rabbis explained the world through several theological principles, in effect creating a series of paradigms that coalesced into models for a righteous life and guidance on how to earn sufficient merit (זכויות) to gain entrance to Olam $H a^{\prime} b a$ (Flesher 2000; Kadushin 1952; Neusner 2000, 2003).

To understand the rabbinic world order, it is necessary to explore the sources from which this order evolved into an integral part of Jewish theology. A major aspect of understanding Rabbinism is to recognise that rabbis used history to describe the present as if the past and present were fused together. This resulted in the formation of paradigms based on a thought-world that incorporated historical events and figures from the past as if the past was as relevant as ever ${ }^{18}$ (Neusner 2003:122-123). Therefore, the history of the nation (Land of Israel) became a timeless religious category, and the sages and prophets of the past remained as relevant in the present as they were thousands of years ago. This concept enabled the formation of a 'timeless paradigm' of the perfect world order from the moment of the creation, at which time the Torah was created in its oral and written forms. Thus, the world continued to exist in this state of total perfection (Neusner 2003:15).

Whereas Qohelet describes the temporal conditions as he perceived them to be, TgQoh presents the condition of humankind as existing in a perfect union with God, as it was in the past, present and in the future world to come, After having served the Lord of the world, he will inherit the world to come as a reward for the works of his hand (TgQoh 5:11). In Neusner's words (2003:178), 'The rabbis explained the world through paradigms that used history to describe the present as if the past and present were fused together'.

In a perfect world, economic and social conditions and the exercise of justice are frozen and endure for all time, ensuring that relationships between people and God and between each other as humans would exist in a 'perfect' state as it was at the time of creation in Eden. The rabbis understood all human endeavours in terms of the Torah and its interpretations by the sages of old. It was only lifelong devotion to Torah study and righteous deeds by which individuals could earn the required rewards for access to the afterlife (Neusner 2003:198-201). Thus, TgQoh speaks paradigmatically of a perfect world that is timeless and attainable to all mankind.

To understand how the concept of a theologically perfect world came into being, it is necessary to examine the sources that contributed to the concept of world order and the development of this rabbinic paradigm:

18.Author's emphasis 
- Torah is at the apex and flowing from that the entire corpus of rabbinic literature that provided the oral and written examples of what constituted a perfect world order. The Torah and its interpretations provided the 'system' for rational thought and argument (Neusner 2003:30, 123).

- The sages and later the rabbis, created the framework of religious and social principles for ensuring rational responses for the enactment of justice. It also bestowed the model for rewarding individuals and protecting the people and Land of Israel by stipulating the values that constituted correct behaviours and moral conduct (Neusner 2003:122-124).

- The paradigm that emerged was founded upon 'a systematic exegesis' that started with scripture as its basis and its midrashic - its explanation and interpretations that shaped the reality and fulfilment of how scripture should be applied in the context of a perfect world order (Neusner 2003:178-179).

- Rabbis believed that mankind lived in a world in which good deeds were rewarded and evil was subject to punishment. This is a major theme in TgQoh, in which a righteous person is judged by God on the day of judgement. ${ }^{19}$

- The thought-world of the rabbis accepted that the world was not always just or rational. Nevertheless, according to the logic of the theological system, the righteous can find solace through Torah and will be rewarded, whereas evildoers will be punished (Neusner 2003:124-125).

The eventual outcome was a world in which time does not exist as a linear concept and this made it possible for TgQoh to depict Solomon as relevant as he was during his lifetime, but portrayed in targumic literature as king, sage, prophet, a rabbi and a judge of the Sanhedrin of old. ${ }^{20}$ It would probably be almost impossible to describe the complexity and logic of the rabbinic approach of a religiously inspired world in any other way than paradigmatically.

\section{An imperfect world: Sources of world disorder}

Mankind and God exist in a complementary relationship: 'they are like one another', man being created in God's image and likeness. ${ }^{21}$ According to Neusner, this is 'the heart of world order' (Neusner 2003:214). Solomon Schechter (1958) and Max Kadushin (1952) noted that the relationship with God is chiefly determined by the articles of faith in Leviticus, 'You shall be holy to me, for I the Lord am holy and I have set you apart from other peoples to be mine' (Lv 20:26) (Kadushin 1952:167177; Schechter 1958:79). Seen from this perspective, the rabbis concluded that man's conduct would need to emulate all the

19.TgQoh $2: 25 ; 4: 6 ; 5: 4 ; 6: 10 ; 8: 6,1-17 ; 7: 15 ; 12: 6 ; 9: 15 ; 9: 3$.

20.Neusner (2003:185) provides this example from Mekhilta to R. Ishmael XXXII: I:1-7: 'Along these same lines, I, "Qoheleth, have been king over Israel in Jerusalem" (Ooh 1:12). This [statement was made] at the outset of the sequence of events, and why then was it stated here? It is because considerations of temporal sequence play no role in the Torah'.

21.Genesis 5:1; Genesis 3:22. standards and ethics of God in a similar sense to that including the fact of the physical likeness between mortals and God at the time of the creation event (Moore 1970:446-448). Hence, any actions and conduct by humankind that transgressed the ethics and moral behaviour as it existed in the Garden of Eden at the time of the creation would result in an imperfect world. This was incorporated into TgQoh's understanding of how the world, that is, mankind, by their specific conduct, caused imperfections to arise in the world. This provided the platform for introducing the concept of sin and how it impacted on nations and individuals. Both sin and repentance are paradigmatically exploited in TgQoh to emphasise the rabbinic theology regarding these two legs of the paradigm that affect the pathway towards the afterlife (TgQoh 1:15; 6:8; 7:28-9; 9:7). In BibQoh the world is depicted as inherently evil and oppressive and lacking in any inclination to consistently punish evil or to deal even-handedly with the good people of the world (BibQoh 5:7; 7:15-16).

The Talmuds concerned themselves with the application of justice in all dimensions of human endeavour but with the focus on Torah study moral values that define righteousness in all earthly activities. For the paradigm of a perfect world, there is an internal logic that justice would evolve into an essential category in a world meant to emulate a theologically 'perfect world'. In rabbinic terms, justice and the enduring stability of the world are governed by correspondence and are '... unchanging and beyond time together with man in relationships of a complementary character' (Neusner 2003:241). This model of justice in a perfect world is premised on depicting God in a perfect relationship as it existed for the people of Israel in the Garden of Eden at the time of the creation (Neusner 2003:198). ${ }^{22}$ This theme also appears where a poor man who studied Torah will join the righteous in Paradise (TgQoh in 6:8); Abraham, who is described in TgQoh as the perfect and just man, 'And I have not found, namely a perfect and just man, without any corruption, as Abraham; from the days of the first Adam till the righteous Abraham was born' (TgQoh 7:28).

\section{Sin in Targum Qohelet}

Targum Qohelet's expansive descriptions of the consequences of sin and for the Jewish people as a whole are found in all 12 chapters of TgQoh. The topics of sin, atonement and retribution as well as its afterlife consequences are radically reinterpreted to alter the purpose of the book to make it read like a treatise on rabbinic dogma. The Targum's relevance was that it should reflect the rabbinic worldview of the nature of the world in a correct relationship between man and God:

For he who is reckoned among the living has something to look forward to - even a living dog is better than a dead lion. Since the living know they will die. But the dead know nothing; they have no more recompense, for even the memory of them has died. (BibQoh 9:5)

For a living dog is better than a dead lion. For the righteous know, that if they sin, they shall be regarded as dead men in the 22.See, for example, Pesiqta deRab Kahana Xxiv. 
world to come, therefore they keep their ways and sin not; and if they sin, they return in repentance. But the wicked do not know any good, for they do not make good their works in their life, and do not know any good in the world to come. And they have no good after their death, for their remembrances are forgotten among the righteous. (TgQoh 9:5)

Sin and evil are insurrections against God (Neusner 2003:261; Schechter 1961:241-242). This rebellion against God ${ }^{23}$ is either a sin of omission, most notably when the study of Torah and obedience to its commandments are purposefully ignored, as a deliberate act of defiance. The result of God's displeasure will be death for the individual person and exile, ${ }^{24}$ and natural catastrophes against Israel and cause a great disruption to the harmony of the world (Kadushin 1952:168, 224-226, 256; Moore 1970:493-496; Neusner 2003:261). Targum Qohelet identifies who amongst the righteous will gain access to the afterlife, whereas the evildoers will be excluded. Note the contrasting views between the two Versions here:

For there is a righteous man perishing in his righteousness, in this world, and his merit is kept for him in the world to come. And there is a wicked man who prolongs his days in his guilt, and the account his evil doings is kept for him for the world to come, to be requited for it in the great day of judgement. (TgQoh 7:15)

In my own brief span of life, I have seen both these things: sometimes a good man perishes in spite of his goodness and sometimes a wicked one endures in spite of his wickedness (BibQoh 7:15).

Targum Qohelet emphasised that death was not the end of human life, but part of a journey towards maintaining a personal relationship with God, in which deserving individuals live in harmony in an eschatological future that was modelled on the land of Israel before the loss of Eden and resurrected in the world to come..$^{25}$

The traditional rabbinic view that sin originated in the Garden of Eden with the story of the forbidden fruit and thereby transgressed the only condition placed upon the first couple at the time of the creation of the world (Moore 1970:474-476; Smolar \& Aberbach 1983:187-188). Death and subsequent punishment for sin was brought into the world by Adam (TgQoh 7):

This I found: That God made the first Adam upright before him and just; and the serpent and Eve seduced him to eat of the fruit of the tree; because those who eat its fruit would be wise to discern between good and evil, and they brought upon him and all the inhabitants of the earth the day of death; and they sought to find many accounts to bring terror upon the inhabitants of the earth. (v. 29) 26

\section{TgQoh 7:9.}

24.The notion that sin leads to death in TgQoh is pervasive, $2: 17,3: 14-19 ; 4: 4,17$ $6: 4,8: 12-14 ; 9: 5-6,16 ; 10: 11$

25.TB Eruvin 13b.

26.See also TgQoh 6:10.

\section{The role of repentance and atonement}

Qohelet struggled to make sense of the inherent injustices in the human condition; he observed that 'Alongside justice, there is wickedness, alongside righteousness, there is wickedness' (BibQoh 3:16). ${ }^{27}$ Targum Qohelet, on the other hand, maintained the classical rabbinic view that the righteous will be rewarded in the world to come, and the wicked will earn what is due to them (Jacobs 1973:350-367; Kadushin 1952:218-219).

Ironically, sin acts as the generator that allows the system (and the paradigm) to enable a process to mitigate the worst impact of sin with forgiveness through repentance and in so doing initiates a process of restoration ${ }^{28}$ (Neusner 2003:260-261; Schechter 1961:293-295). Murder, fornication and idolatry are classified as absolute sins in a special category because of their association with the generation of the flood. But these transgressions are to be avoided and can be forgiven, provided an act of sincere atonement takes place before a person's death (TgQoh 8):

And when a sinner does evil a hundred years, and time is given him from the Lord that he may repent it, it is nevertheless revealed to him by the Holy Spirit. (v. 12)

In theological terms, sin embodies the chaos of the world, but when followed by an act of repentance, a systematic progression follows that ultimately restores balance and order in the relationship between humankind and God. However, the one major sin that is entirely unforgivable is that of the rejection of the Torah (TgQoh 1:15; 6:6). ${ }^{29}$

According to B. Nedarim 3:1, that sin occurred in the Garden of Eden irrevocably changed the course of God's relationship with Adam and Israel, and this partly brought about the need for recorded scripture (Qoh 1):

Said R. Ada b. Hanina: If the Israelites had not sinned, to them would have been given only the Five Books of the Torah and the book of Joshua alone, which involves the division of the Land of Israel. How come? 'For much wisdom proceeds from much anger'. (v. 18)

This created the theological explanation for the existence of imperfection in the world, and it in turn evolved into a rationale for the creation of a system for repentance and atonement, 'Sin is so defined as to accommodate the possibility of regeneration and restoration' (Neusner 2003:261). The paradigm is presented as a benchmark for perfection. When the first sin had been committed in the Garden of Eden it was theologically interpreted as a direct rebellion against God. Adam exercised his own conscious

27.BibQon 3:16-17; 4:1-2; 7:15-18; 8:11-14; 9:1-3.

28.Psalms 25:8

29.'All Israel has a portion in the world to come, for it says, "Your people, all of them righteous, shall possess the land forever" ... And these are the ones who have no portion in the world to come: he who maintains that the resurrection is not a portion in the world to come: he who maintains that the resurrection is not a
biblical doctrine, that the Torah was not divinely revealed and an epikoros ... (one who rejects the Torah)' Sanhedrin10:1 
free will to reject the Torah and God. The paradigm asserts that humankind is therefore answerable to God for its wilful transgressions, and in turn, this demanded of the sinner to make a conscious and sincere effort to ask for forgiveness (Moore 1970:465; Neusner 2003:276-280). ${ }^{30}$ Moore (1970:520) explained, 'Repentance is the sole, but inexorable, condition of God's forgiveness and the restoration of his favour, and the divine forgiveness and favour are never refused to genuine repentance'. According to Kadushin (1972:15), repentance is an integral part of the core concept termed 'God's Love'. The process allows for a form of generative of rehabilitation.

The righteous, in rabbinic terms, are equated with individuals who are devoted to Torah study, a tsaddik, a position that guaranteed a place in the afterlife. In TgQoh Solomon is depicted as a paragon of sage-like wisdom and piety connected to an ancient lineage, of rabbis, down the ages. Solomon's role was used as a hermeneutic specifically to introduce and incorporate appropriate theological doctrines of rabbinic Judaism into the text and align them with the views of scripture (Levine 1978:40-41, 66-67). The paradigm modelled the role of Solomon as a sage and king-prophet was greatly expanded in TgQoh, and especially in QohRab. This gave the paradigm its authority and the text its religious authenticity (Alexander 2011:92). However, in TgQoh 1:12-13, the targumist inserted the failings of Solomon who was tricked by the wicked Ashmodai to reinforce the notion of the fallibility of all humans to break the decree of God.

In TgQoh, the themes of sin, repentance, atonement, punishment and forgiveness are interspersed throughout the text in various contexts in the following verses: TgQoh 1:4, 15,$18 ; 2: 12,14 ; 3: 11,14,18,19 ; 4: 17 ; 6: 2,6 ; 7: 2,21 ; 8: 11,14 ; 9: 5$, 16,$18 ; 10: 6,11 ; 12: 13$. The outstanding two features are that 'sin situations' are accompanied by warnings of death unless sufficient and sincere prayer and repentance have been undertaken.

Repentance had become a theological necessity if one follows the logic of the Targum that states, 'since there is no righteous man on earth' (TgQoh 7:20); Sin is followed by repentance or teshuva, a 'return to God' (Neusner 2003:277). The theology of the late Amoraim ascribed repentance as a model for the renewal of faith to even the most egregiously wicked (Cathcart \& Gordon 1989:156-157). The paradigm of a perfect world is thus almost complete. Through a process of moving from sin to repentance and forgiveness by prayer, the paradigm provides the steps for a renewal of the cosmic relationship between God and humankind to take place and thereby for harmony to reign over the world (Levine 1978:79).

If $\sin$ is what introduces rebellion and change, and the will of man is what constitutes the variable in disrupting creation, then the theology of the rabbinic canon makes provision for restoration through the free exercise of man's will (Neusner 2003:276).

30.And man cannot stand in judgment with the Lord of the world, who is stronge than he' (TgQoh 6:11)
There is one condition that sinners must undertake sufficient and sincere atonement to reconcile with God. Unlike the hebel - infused bleakness in BibQoh, in the Targum there is hope for mercy and justice based on the 'restorationist character of Jewish theology' (Neusner 2003:294) ${ }^{31}$ Repentance was a theological necessity for maintaining world order and an integral feature of most rabbinic and thus targumic literature. $^{32}$

According to the theology of TgQoh, the concept of sin and subsequent repentance and atonement follows the theological view that repentance became the one indispensable requirement for the individual and the Land of Israel's salvation. Except in those instances where forgiveness was not possible and the punishment was consignment to Gehenna. $^{33}$ The full concept of forgiveness is not present in BibQoh; however, the TgQoh introduces the concept with the thoughts, language and the rabbinic doctrines regarding repentance leading to the notion of everlasting life (Ezk 18):

Rabbi Shmuel bar Naḥmani said that Rabbi Yonatan said: Great is repentance, which lengthens the years of a person's life, as it is stated: 'When the wicked man turns from his wickedness that he has committed, and does that which is lawful and right, he will preserve his life'. (v. 27) ${ }^{34}$

Emanating from the paradigm of a perfect world, God is depicted as merciful and forgiving to persons who engage in meaningful reflection and who atone. These actions repair the defect in the relationship and restore the world once again to its perfect state and complete the paradigm. This occurs, according to Neusner, when a person who has died but is deemed holy in God's eyes, will be able to join the community of the righteous. The righteous in the Olam Ha'ba will participate in the next world, that is, Eden, in an everlasting celebration of Shabbat and Torah learning (Neusner 2003:486-489). ${ }^{35}$

In TgQoh, all the doctrines of rabbinic theology are encapsulated as an organic whole with its internal logic. This is clearly expressed paradigmatically by the use of specific language features, by which lexemes and syntax form holistic paradigms that are consistently presented in terms of sin, repentance, atonement and reconciliation with God. This paradigm becomes a generative doctrine founded on the principle that God will not tolerate forms of 'structural injustice' and would thus be excluded from participation in a perfect world unless they adhere to the conditions of remorse and atonement (Neusner 2003:9-11).

31.TgQoh 2:10-11.

32.Gehenna it was said was formed on the second day of creation, together with the angels, the heavens and fire (Gn Rab 4:6, 11:9). It was important for the rabbis to depict the concept.

33.The range of offences that warranted Gehenna were essentially those that could be categorised as sins of omission or sins that failed to meet the ethical and moral standards required for righteous living according to the demands of Torah and thus exclusion from the eternal afterlife.

34.TB Yoma 86b.

35.People and God relate by means of a transactional relationship: if someone who sins is prepared to atone then they will earn entry into Eden, in much the same way, Adam and Eve were forgiven; Neusner calls this 'a measure for measure' (Neusner 2003:294). 
Targum Qohelet provides the ethical and moral basis to act as a 'road map' in which the concept of the afterlife becomes a central feature for an existentialist solution in which humankind can find solace and hope in an irrational world. Death, through the afterlife, ironically offers hope and simultaneously supplies the wisdom that Qohelet sought. The notion of a 'world to come' is paradigmatically inseparable from the theological chain of sin, repentance, atonement, rewards for meritorious deeds (זכויות) and also punishment, but most importantly the study and devotion to Torah. Targum Qohelet 1:3 is a direct response to Qohelet's hebel statement in the superscript 'All is hebel', by which it refutes all the negative implications of hebel with an offer of hope for everlasting life on condition that people devote their entire lives in this world to Torah study and righteousness.

What value is there to man, after his death, from all his labour which he laboured under the sun in this world, other than if he studied the word of God, to receive a good reward in the world to come from before the Lord of the world (TgQoh 1:3).

\section{Conclusion}

This article has demonstrated that the translators of TgQoh found it imperative to create an entirely different approach to Qohelet's wisdom in which life was unremittingly cruel, uncertain and arbitrary from birth to death. The Targum's aim was to overturn the pervading sense of hopelessness (hebel) and to give people guidelines with which to find a bridge between a fulfilling life and the hope of a postmortem existence in a future Olam $\mathrm{Ha}^{\prime} b a$. The targumic translations were used as hermeneutical devices not only to interpret the original but also to reveal the true meanings of the Hebrew versions. This was the practice and tradition that rabbis were trained to do: interpretative discourse through exegesis and hermeneutical exploration in a ceaseless quest to find meanings from texts (Boyarin 1990:ix). In TgQoh's case, the implications attached to hebel became, in a sense, a rabbinical 'masterclass' to exegetically explain BibQoh's frustrations with regard to death and the afterlife by seeking validation from rabbinical literature. The targumist achieved this by maintaining its focus on the intrinsic characteristics of the Targum genre even though the contradictory and controversial sections of the base text remained (Alexander 2011:86).

Presenting the translation in the form of a collection of religious paradigms made it possible to reinforce the key constituents of a theologically perfect world order. On viewing the text as it comes across, it appears as a hodgepodge of many disparate additional texts - items that seem tangential to its original Hebrew version. ${ }^{36}$

It is uncertain how TgQoh was presented to its intended audience. My theory is that it was used in the batei midrash for 36.For more on the uses of TgQoh see Alexander (2011:89-90). teaching purposes as an exegetical tool to flesh out the hidden meanings of scripture and as a means to reveal the rabbinical contexts whilst at the same time acting as a rebuttal against the secular nature of the Hebrew original. Its use may have been as a hermeneutical reference during studies and debates, where students and teachers would refer to TgQoh in the same way as they would use a midrash, the Talmuds and various other texts from rabbinical literature. Its value as a study tool lies in the fact that it represents a different perspective on wisdom literature and for understanding the role and meaning of Torah, not only from the established sages of the rabbinic past but also from the perspective of translators who created a different dynamic of learning about Torah and understanding its many variant literatures. ${ }^{37}$

For scholars, the complexity of the Aramaic text requires a methodical approach. This study proposes that TgQoh can be dissected and analysed by identifying the paradigms that are embedded in the narrative to uncover the connectedness of the vast web of its theological components. This is not too far from the hermeneutical practice of derash and sod encountered in the study schools.

\section{Acknowledgements}

The author thanks Prof. Johann Cook.

\section{Competing interests}

The author declares that he has no financial or personal relationships that may have inappropriately influenced him in writing this research article.

\section{Author's contribution}

L.L. is the sole author of this research article.

\section{Ethical considerations}

This article followed all ethical standards for research without direct contact with human or animal subjects.

\section{Funding information}

This research received no specific grant from any funding agency in the public, commercial or not-for-profit sectors.

\section{Data availability}

Data sharing is not applicable to this article as no new data were created or analysed in this study.

\section{Disclaimer}

The views and opinions expressed in this article are those of the author and do not necessarily reflect the official policy or position of any affiliated agency of the author.

37. Educated readers of the bible may have understood these targumim as part of the complex of interrelated literatures of holy books and as practitioners of the hermeneutic processes were aware how texts randomly included and combined biblical verses into a Targum. See also Gottlieb $(2014: 5,8)$. 


\section{References}

Alexander, P.S., 2007, The Targum of lamentations: Translated with a critical introduction, apparatus, and notes, Liturgical Press, Collegeville, MN.

Alexander, P.S., 2011, 'Translation and Midrash completely fused together? The form of the Targums to canticles, lamentations and qohelet', Aramaic Studies 9(1), 83-101, 102-115. https://doi.org/10.1163/147783511X594861

Boyarin, D., 1990, Intertextuality and the reading of midrash, Indiana University Press, Indianapolis, IN.

Cathcart, K. \& Gordon, R.P., 1989, The Targum of the minor prophets, The Aramaic Series 14, Michael Glazier, Wilmington, NC.

Chomsky, N., 1993, Language and thought, Moyer Bell, Chicago, IL.

Flesher, P.V.M., 2000, 'The resurrection of the dead and the Palestinian Targums to the Pentateuch', in A. Peck \& J. Neusner (eds.), Judaism in late antiquity death. Part 4: Death, life-after-death, resurrection \& the world-to-come, Brill, Leiden.

Flesher, P.V.M. \& Chilton B., 2011, The Targums: A critical introduction, Baylor Press, Waco, TX.

Fox, M., 1999, Qoheleth and his contradictions, Bible and Literature Series 18, Almond Press, Sheffield.

Gottlieb, L., 2014, 'Composition of Targums after the decline of Aramaic as a spoken language', Aramaic Studies 12(1), 1-8. https://doi.org/10.1163/1745522701201004

Jacobs, L., 1973, A Jewish theology, Behrman, New York, NY.

Kadushin, M., 1938, Organic thinking: A study in rabbinic thought, Bloch Publishing Co., New York, NY.

Kadushin, M., 1952, The rabbinic mind, Bloch Publishing Company, New York, NY.

Knobel, P.S., 1991, The Targum of Qohelet: Translated with a critical introduction, apparatus and notes, The Aramaic Bible Series 15, Liturgical Press, Collegeville, MN.

Kuhn, T., 1962, The structure of scientific revolutions, Chicago University Press, Chicago, IL.
Küng, H., 1993, 'Declaration toward a global ethic', Información Sobre Nicaragua $Y$ CentroAmérica, viewed 17 July 2020, from https://www.envio.org.ni/articulo/1612.

Levine, E., 1978, The Aramaic version of Qohelet, Sepher-Hermon Press, New York, NY. Levine, E., 1988, The Aramaic version of the Bible, De Gruyter, Berlin.

Manns, F., 1992, 'Le Targum de Qohelet - Manuscript Urbinati I: Traduction et commentaire', Liber Annus 42, 18-31.

Merino, L.D., 1987, Targum de Qohelet, Edicion Príncipe del Ms. Villa Amil n. 5 de Alfonso de Zamora, Biblioteca Hispana Biblica, Madrid.

Mittwede, S., 2012, 'Research paradigms and their use and importance in theological inquiry and education', Journal of Education in Christian Belief 16(1), 23-40. https://doi.org/10.1177/205699711201600104

Moore, G.F., 1970, Judaism in the first centuries of the Christian era. The age of the Tannaim, 2 vols., Harvard University Press, Cambridge, MA.

Myers, B., 2008, 'The stratification of knowledge in the thought of T.F. Torrance', Scottish Journal of Theology 6(1), 1-15. https://doi.org/10.1017/S003693060700381X

Neusner, J., 2000, Dual discourse, single Judaism: The category-formations of the Hallakah and of the Aggadah defined, compared and contrasted, Studies of Judaism Series, University Press of America, Lanham.

Neusner, J., 2003, Handbook of rabbinic theology: Language, system, structure, Brill, Leiden.

Samely, A., 2011, 'The Targums within a new description of Jewish text structures in antiquity', Aramaic Studies 9(1), 5-39. https://doi.org/10.1163/147783511X594825

Schechter, S., 1958, Studies in Judaism: Essays on persons, concepts, and movements of thought in Jewish tradition, Meridian Books, New York, NY.

Schechter, S., 1961, Aspects of Rabbinic theology: Major concepts of the Talmud, Schocken Books, New York, NY.

Schoors, A., 2013, Ecclesiastes, Peeters, Leuven.

Seow, C.L., 1997, Ecclesiastes: A new translation with introduction and commentary, The Anchor Bible Series, Doubleday, New York, NY

Smolar, L. \& Aberbach, M., 1983, Studies in Targum Jonathan to the Prophets, Ktav Publishing House, Baltimore, MD.

Taradach, F. \& Ferrer, J., 1998, Un Targum de Qohelet: Edition Princeps du Ms. de Salamanca, Labor et Fides, Geneva. 